\title{
Comparative Study Of Methods To Educate Children Of Generation X With Millennial Generation Children Comparative Study Of Parenting Methods Among X- Gens And Z-Gens
}

\author{
Budi Hutagalung \\ \{budiframa10@gmail.com\} \\ Postgraduate Program, Pelita Kebenaran School of Theology
}

\begin{abstract}
The difference in generation between $\mathrm{X}$ and $\mathrm{Z}$ can lead to differences and misunderstandings in education, this is the case for the self-interest of parents in education in this generation. The pressure cannot be achieved in the generation of $\mathrm{Z}$ and can be stressful in children. This can be caused by the development of digital revolution that has changed the lives, education, culture, etc. The study aims to find out the comparison of educational methods to this generation, after which the person should be able to apply the education to the experience and how to produce a good method in education.
\end{abstract}

Keyword : Education, Millennial

\section{Introduction}

Since the emergence of the Generation Theory put forward by Graeme Codrington and Sue Grant Marshall, we introduced the term baby boomers (born 1946-1964), generation X (born 1965-1980), generation Y (born 1981-1994), generation Z ( born in 1995-2010) and Alpha generation (in 2011-2025). Everything related to work is often associated with the characteristics of that generation. It was revealed nothing else to find a middle ground so that the generations could understand and understand each other. Likewise in educating, educational methods are fundamental in achieving effective and active learning outcomes that will encourage students to be able to develop their potential to be better, starting from the level of intelligence, personality, morality and useful skills, both in society and society. Differences in generation of parents when educating children born in generation $\mathrm{X}$ and generation $\mathrm{Z}$ can lead to differences and misunderstandings in looking at education.

\section{Research Method}

In research, knowledge of the subject is the subject of research which has the same openness as possible in education. Each subject also has a different nurturing problem. The type of research used is qualitative. Theoretical understanding of qualitative research is research that is limited to the effort to express a problem and in its current state so that it is only a disclosure of facts to find explanatory principles that lead to and inference. Each generation has a different parenting style. Including generation $\mathrm{Z}$ who now have parenting that is very different from the previous generation. Parents of the first millennial generation are considered to tend to over-focus on children and have a big role in determining the future or things that their offspring consume. Full involvement of parents in children's lives, especially 
those who are still in basic education or are still teenagers. The style dictates the parents of millennial are abandoned. Now, collaboration with children is in depth in the case of the Indonesian military. During the $\mathrm{X}$ generation, parents were found who immediately scolded their children when they made mistakes, without wanting to know the explanation from the child first and take another approach so that the child was deterred. Now, millennials have another approach when they find children wrong. The perspective of the parents of parents is not as common as the future. Millennial parents regard their children as friends. Raising and educating this generation of $\mathrm{Z}$ children certainly needs certain ways, in contrast to generation $\mathrm{X}$, the familiarity of the $\mathrm{Z}$ generation with technology makes this generation $\mathrm{Z}$ child have advantages and disadvantages they have. Here is the comparison of parents' ways of educating, raising their characteristics in generation $\mathrm{X}$ and $\mathrm{Z}$ :

Generation X:

a. Parents play an important role in determining the role of childbirth.

b. Parents have excessive focus related to what they consume.

c. Study the exact efficiency, aim to use the child in the age of discomfort with the verbose.

d. Hanyama will find a useful thing.

e. Like flexible student learning.

Generation Z:

a. Invite them to do activities together, Generations have many advantages and disadvantages such as individual attitudes. This trait makes them tend to be selfish because they think too much of themselves. This can be due to the habit of spending time using gadgets rather than around the environment since childhood. Generation $\mathrm{Z}$ must always be considered so that they are more sensitive to the environment.

b. Treat the generation $\mathrm{Z}$ child gently and patiently, One way parents can do this is to treat them gently and patiently. Never be rude to them. As long as you know the character and character of the child well, parents can treat the $\mathrm{Z}$ generation of children well.

c. Become a good model for children, Teaching children is of course not only done only by theory. Parents also have to set an example to children.

d. Provide logical consequences, be assertive, disciplined and consistent.

e. Instill positive values in children in their daily lives.

f. Create effective communication with children so parents understand what children are doing.

g. Give love without conditions, Parents also need to understand that every child has potential and disadvantages. Love children with all their strengths and weaknesses by giving them support to develop the potential that they have and guide them when faced with their shortcomings. Parents also see that their groups are loving children with the same love as God, who loves not being sentimental, but you who care to emphasize the right things.

Percentive negative data characteristics of X Generation and Generation Z:

Positive Characteristics

\begin{tabular}{llll}
\hline No & KarakteristikPositif & Gen. X (\%) & Gen.Z (\%) \\
\hline 1 & Perduliteknologibaru & 65 & 90 \\
2 & Sukamencoba-coba & 78 & 85 \\
3 & Aktif & 70 & 90 \\
4 & Kreativitastinggi & 69 & 87 \\
5 & Tidaktakutdenganperubahan & 66 & 80 \\
6 & Ide-ide Brilian & 64 & 86 \\
\hline
\end{tabular}




\begin{tabular}{llll}
\hline No & KarakteristikPositif & Gen. X (\%) & Gen.Z (\%) \\
\hline 7 & Pintar & 70 & 80 \\
8 & Handal & 75 & 85 \\
\hline
\end{tabular}

Note:

- From this data it can be concluded that the Z Generation is more consistent with the technology compared to Generation X.

- The activity level of $Z$ Generation is also better than Generation X.

Negative Character

\begin{tabular}{llll}
\hline No & KarakteristikNegatif & Gen. X (\%) & Gen.Z (\%) \\
\hline 1 & Individualis & 67 & 87 \\
2 & Mudahbosan & 60 & 85 \\
3 & Ego sentris & 55 & 90 \\
4 & Tampilbeda & 53 & 87 \\
5 & Tidaksabar & 48 & 80 \\
6 & Tidakpeduli & 45 & 90 \\
7 & Komitmendanloyalitasrendah & 28 & 70 \\
8 & Tidakpernahserius & 18 & 85 \\
\hline
\end{tabular}

Note:

- Z-level selfishness accounts for $90 \%$ compared to Generation X only $55 \%$

- Uncertainness The generation of $\mathrm{Z}$ is higher than that of Generation $\mathrm{X}$

\section{Positive Character}

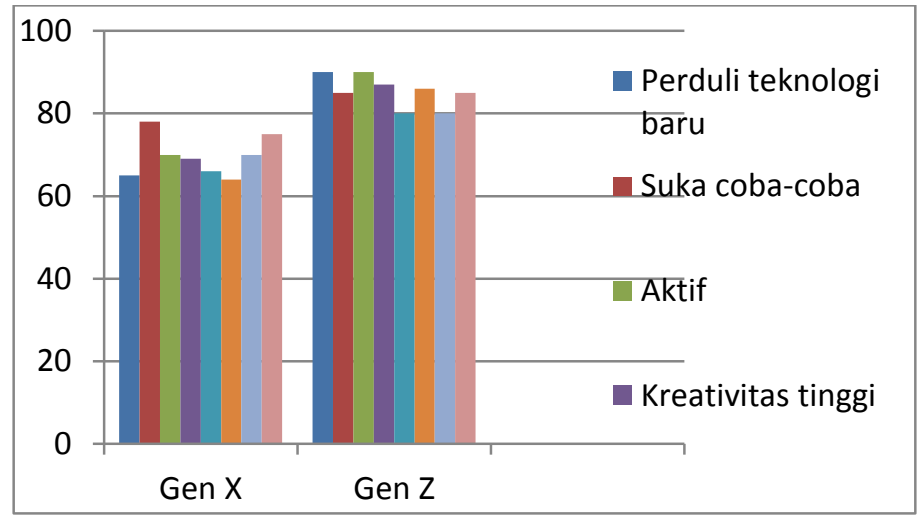

\section{Negative Character}




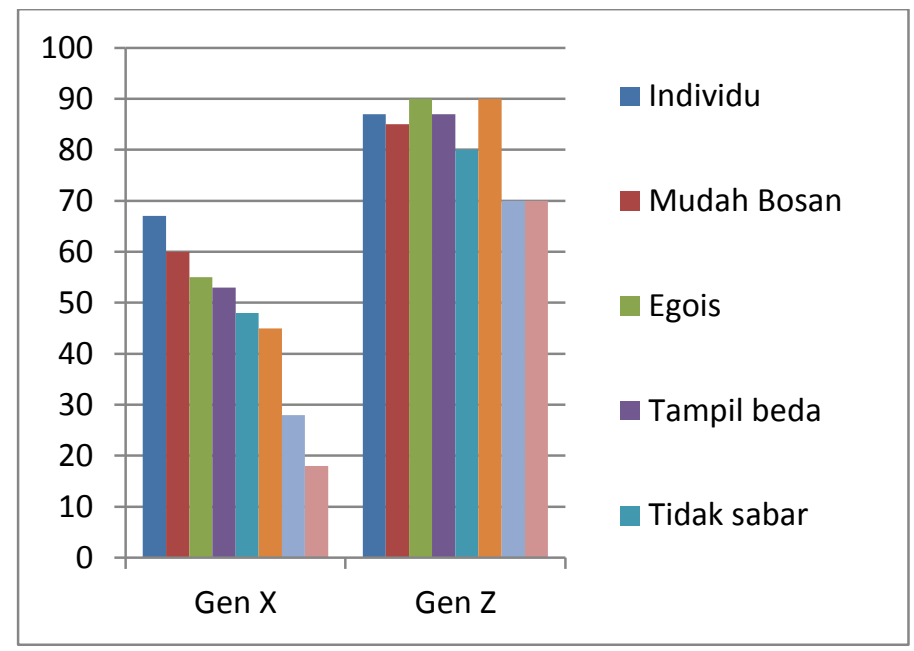

\section{Results and Discussions}

During the $\mathrm{X}$ generation, parents were found who immediately scolded their children when they did wrong, without wanting to know the explanation from the child first and take another approach so that the child deterred. Now, millennials have another approach when they find children wrong. The perspective of the parents of parents is not as common as the future. Millennial parents consider their children to be friends. Raising and educating this generation of $\mathrm{Z}$ children certainly needs certain ways, in contrast to generation $\mathrm{X}$, the familiarity of the $\mathrm{Z}$ generation with technology makes this generation $\mathrm{Z}$ child have advantages and disadvantages they have. Here is the comparison of parents' ways of educating, raising their characteristics in generation $\mathrm{X}$ and $\mathrm{Z}$ :

Generation X:

a. Parents play an important role in determining the role of childbirth.

b. Parents have excessive focus related to what they consume.

c. Study the exact efficiency, avoid wearing a child on the age of discomfort with the verbose.

d. Hanyama will find a useful thing.

e. Like flexible student learning.

Generation Z:

a. Invite them to do activities together.

Generations have many advantages and disadvantages such as individual attitudes. This trait makes them tend to be selfish because they think too much of themselves. This can be due to the habit of spending time using gadgets rather than around the environment since childhood. Generation $\mathrm{Z}$ must always be considered so that they are more sensitive to the environment.

b. Treat the generation $\mathrm{Z}$ child gently and patiently.

One way parents can do this is to treat them gently and patiently. Never be rude to them. As long as you know the character and character of the child well, parents can treat the $\mathrm{Z}$ generation of children well.

c. Become a good model for children.

Teaching children is of course not only done only by theory. Parents also have to set an example to children.

d. Provide logical consequences, be assertive, disciplined and consistent. 
e. Instill positive values in children in their daily lives.

f. Create effective communication with children so parents understand what children are doing.

g. Give love without conditions. Parents also need to understand that every child has potential and disadvantages. Love children with all their strengths and weaknesses by giving them support to develop the potential that they have and guide them when facing shortcomings. Parents also see that one of their groups is loving children with the same love as God who loves who is not sentimental, but you who care to emphasize righteousness.

\section{Conclusion}

In differences in educating the $\mathrm{X}$ and $\mathrm{Z}$ generations that have a very long age range, the role of parents is very important in this matter. The way of thinking parents used to educate children in the $\mathrm{X}$ generation can no longer be used when educating children living in generation Z. Growing digital revolution is increasingly extraordinary so that it changes the joints of life, culture, civilization and education, so characters are always able to adjust to Guidelines for the development of time, because parents must be sensitive to the advances in technology that are always developing, they must actively find out the latest information about the pattern of educating children, such as attending seminars, participating in support groups provided the government can even learn about available applications in the Playstore that is available in every Android cellphone about how to educate, supervise children.

\section{References}

[1] Alif Widjaja: Komunikasi Interpersonal Lintas Generasi Untuk Menghadapi Stres Akademik Pada Anak, 2017

[2] HidayatDasru:KomunikasiAntarpribadi. Yogyakarta:Grahallmu (2012)

[3] https://m.kumparan.com/tunaiku-official/akrab-dengan-internet-dan-gadget-ini-5-hal-pentingdalam-mendidik-anak-anak-generasi-z-1500638898300, diaksesterakhirtanggal 25 Februari 2019, pukul 18.30 wib

[4] https://tirto.id/mengasuh-anak-ala-milenial-cvLg, diaksesterakhirtanggal 25 Februari 2019, pukul $18.00 \mathrm{wib}$

[5] https://www.kompasiana.com/angelsari/5c14c3cbc112fe4b2060d392/teori-generasi-adakahperbedaan-dan-persamaan-karakter, diaksesterakhirtanggal 25 Februari 2019, pukul 19.30 wib

[6] Jalaludin:PsikologiKomunikasi.Bandung:RemajaKarya (2003)

[7] James H. McMillan \& Sally Schumacher: Research In Education: A Conceptual Introduction.Publisher (2000)

[8] Smartmama.com/2018/05/14/positive-parenting-pola-asuh-untuk-generasi-z/, diakses terakhir tanggal 25 Februari 2019, pukul 19.00 wib

[9] Suryanto:PembelajaranKarakter di Sekolah. Yogyakarta (2014)

[10] William:Menjadi Orang Tua yang Berwibawa. Jakarta:Imanuel (1995) 